\title{
Musyawarah dalam Penentuan Ganti Kerugian Bagi Pelaksanaan Pembangunan untuk Kepentingan Umum
}

\section{Tri Susilaningsih}

Tri Susilaningsih; Fakultas Hukum Universitas Merdeka Malang; Jl. Terusan Dieng No.62-64; Malang; 65115; Indonesia.

\section{ARTICLEINFO}

Article history:

Received 2018-10-28

Received in revised form

2018-11-10

Accepted 2018-12-01

Kata kunci: Pengadaan Tanah, Kepentingan Umum, Ganti

Kerugian.

Keywords: Judge's Consideration, Criminal Acts, Child.
Corresponding Author:

Tri Susilaningsih

E-mail address: trisusilaningsih25@gmail.ac.id

\section{Abstrak}

Pengadaan tanah merupakan kegiatan untuk menyediakan tanah bagi pembangunan untuk kepentingan umum. Pelaksanaan pengadaan tanah dilakukan berdasarkan Undang-Undang Nomor 2 Tahun 2012 Tentang Pengadaan Tanah Bagi Pembangunan Untuk Kepentingan Umum dan ketentuan-ketentuan terkait yang mengaturnya. Undang-undang ini dibuat untuk meningkatkan kesejahteraan dan kemakmuran bangsa, Negara dan masyarakat tetap menjamin kepentingan hukum Pihak yang Berhak. Pengaturan Pengadaan tanah dalam Undang-Undang memang tepat tetapi dari segi substansi, Undang-Undang yang strategis dan berdampak luas ini menyisakan beberapa catatan. Jadi Undang-Undang yang disahkan tanggal 14 Januari 2012 ini juga belum bisa menjamin perolehan tanah untuk pembangunan. Menurut konsepsi hukum tanah nasional, pada prinsipnya pengadaan tanah/ perolehan tanah dilakukan dengan cara musyawarah antara Instansi pemerintah yang memerlukan tanah dengan Pihak yang Berhak, dalam hal penentuan lokasi, bentuk dan/atau besarnya Ganti Kerugian. Namun ada kalanya musyawarah tidak tercapaiatau mengalami kegagalan.

\section{Abstract}

Land acquisition is an activity to provide land for development in the public interest. The implementation of land acquisition is carried out based on Law Number 2 of 2012 concerning the Procurement of Land for Development in the Public Interest and related provisions governing it. This law was made to improve the welfare and prosperity of the nation, the State and society still guarantee the legal interests of the Entitled Party. The regulation of land acquisition in the law is correct but in terms of substance, this strategic and broad-impact law leaves a few records. So this Law which was passed on January 14, 2012 also cannot guarantee the acquisition of land for development. According to the conception of national land law, in principle land acquisition / land acquisition is carried out by means of deliberations between government agencies that require land with entitled parties, in terms of determining the location, form and / or amount of compensation. But there are times when deliberation is not reached or fails. 


\section{Musyawarah dalam Penentuan Ganti Kerugian Bagi Pelaksanaan Pembangunan untuk Kepentingan Umum}

Tri Susilaningsih

\section{Latar Belakang}

Setiap pembangunan di Indonesia bagi instansi yang memerlukan tanah harus dilakukan dengan cara pengadaan tanah bagi kepentingan umum. Pengadaan tanah bagi kepentingan umum kerap kali harus mengorbankan nilai kepentingan individu. Dengan memiliki tanah dapat diketahui hak atas tanah apa yang dimiliki, apakah Hak Milik, Hak Guna Usaha atau hak atas tanah yang lainnya. Hak atas tanah tersebut bersifat individu dan pribadi dalam konsepsi hukum tanah nasional mengandung unsure kebersamaan. Unsur kebersamaan atau unsur kemasyarakatan ada pada tiap hak atas tanah, karena semua hak atas tanah secara langsung maupun tidak langsung bersumber pada Hak Bangsa, yang sebagai hak bersama (Harsono, 2013). Seseorang yang memiliki tanah tidaklah dapat dibenarkan bahwa tanahnya itu akan dipergunakan atau tidak dipergunakan sematamata untuk kepentingan pribadinya, apalagi kalau hal itu menimbulkan kerugian bagi masyarakat. Kepentingan umum dengan kepentingan individu pemilik yang dijabarkan dari fungsi ekonomi tanah. Artinya, pada saat dibutuhkan demi kepentingan umum, kepentingan individu bisa dikompromikan, bahkan dikalahkan, dan hak milik atas tanah harus dilepaskan (Suryaningtyas, 2005).

Sifat pribadi hak-hak atas tanah yang sekaligus mengandung unsur kebersamaan atau kemasyarakatan tersebut, dalam Pasal 6 UndangUndang Pokok Agraria dirumuskan dengan katakata: "Semua hak atas tanah mempunyai fungsi sosial". Salah satu persoalan yang dihadapi sehubungan dengan pelaksanaan kepentingan umum adalah menentukan titik keseimbangan antara kepentingan umum dan kepentingan pribadi di dalam pembangunan (Mahendra, 1996).

Pengadaan tanah selalu menyangkut dua sisi dimensi yang harus ditempatkan secara seimbang, yaitu kepentingan masyarakat dan kepentingan pemerintah. Pihak pemerintah dalam hal ini adalah penguasa harus melaksanakan pembangunan untuk meningkatkan kesejahteraan masyarakat atau demi kepentingan Negara dan rakyatnya sebagai salah satu bentuk pemerataan pembangunan. Sedangkan pihak masyarakat sebagai penyedia sarana untuk melaksanakan pembangunan tersebut karena rakyat atau masyarakat memiliki lahan yang dibutuhkan sebagai bentuk pelaksanaan pembangunan. Masyarakat dalam hal ini juga membutuhkan tanah sebagai sumber penghidupan (Sumardjono, 2001).

Pengadaan tanah untuk pembangunan hanya dapat dilakukan atas dasar musyawarah antara Pihak yang Berhak atas tanah dengan pihak yang membutuhkan tanah mengenai bentuk dan/atau besarnya ganti kerugian yang akan diberikan kepada pihak yang berhak itu sendiri. Artinya pengadaan tanah harus dilakukan dengan musyawarah untuk mencapai mufakat dalam pemberian ganti kerugian kepada yang berhak atas tanah tersebut tidak dengan cara lain selain pemberian ganti kerugian (Limbong, 2015). Setelah ada kesepakatan dari musyawarah mengenai bentuk/dan atau besarnya ganti kerugian segera dilaksanakan pengadaan tanahnya. Namun jika tidak ada titik temu dari musyawarah tersebut, artinya tidak ada kesepakatan mengenai ganti kerugiannya inilah yang menjadi permasalahan.

Istilah "Pengadaan Tanah" dikenal sejak adanya Keputusan Presiden Nomor 55 Tahun 1993 Tentang Pengadaan Tanah Bagi Pelaksanaan Pembangunan Untuk Kepentingan Umum, Peraturan Presiden Nomor 36 Tahun 2005 Tentang Pengadaan Tanah Bagi Pelaksanaan Pembangunan Untuk Kepentingan Umum, yang kemudian dirubah menjadi Peraturan Presiden Nomor 65 Tahun 2006 Tentang Perubahan Peraturan Presiden Nomor 36 Tahun 2005 Tentang Pengadaan Tanah Bagi Pelaksanaan Pembangunan Untuk Kepentingan Umum dan Undang-Undang Nomor 2 Tahun 2012 Tentang Pegadaan Tanah Bagi Pembangunan Untuk Kepentingan Umum. IPengadaan Tanah menurut Pasal 1 angka 2 Undang-Undang Nomor 2 Tahun 2012 adalah kegiatan menyediakan tanah 
dengan memberi ganti kerugian yang layak dan adil kepada pihak yang berhak. Artinya pengadaan tanah hanya dilakukan dengan cara memberi ganti kerugian kepada pemegang hak atas tanah (pihak yang berhak) yang diambil bagi pembangunan untuk kepentingan umum (Limbong, 2015).

Permasalahan dalam hukum pertanahan yang tidak pernah selesai dari waktu ke waktu adalah permasalahan pengambilan tanah kepunyaan masyarakat atau penduduk bagi pelaksanaan pembangunan proyek pemerintah untuk kepentingan umum. Permasalahan pengadaan tanah seperti pembebasan tanah, pengambilan tanah, pencabutan hak atas tanah, atau dengan nama apapun selalu melibatkan dua kepentingan yang harus ditempatkan seimbang. Kedua pihak antara pemerintah dan rakyat harus sama-sama memperhatikan dan mentaati kaedah-kaedah hukum yang mengatur dan akibat atau dampak tindakan tersebut (Sugiharto, dkk, 2015).

Pelaksanaan pengadaan tanah harus memperhatikan berbagai asas, yaitu: asas-asas pengadaan tanah, asas-asas penguasaan tanah dan perlindungan hukum bagi pemegang hak atas tanah serta asas-asas ganti kerugian agar tidak merugikan salah satu pihak. Adapun asas-asas tersebut adalah: a). Asas-asas pengadaan tanah, yaitu: asas kemanusiaan, asas keadilan, asas kemanfaatan, asas kepastian, asas keterbukaan, asas kesepakatan, asas keikutsertaan, asas kesejahteraan, asas keberlanjutan dan asas keselarasan. Implementasi pengadaan tanah juga perlu memperhatikan beberapa prinsip yang tersirat dalam perundang-undanganl dan ketentuan terkait lyang mengaturnya, yaitu: Penguasaan dan penggunaan tanah oleh siapapun dan untuk keperluan apapun harus ada landasan haknya; Semua hak atas tanah secara langsung maupun tidak langsung bersumber pada hak bangsa; Cara untuk memperoleh tanah yang sudah dihaki oleh seseorang/badan hukum harus melalui kata sepakat antar pihak yang bersangkutan; dan dalam keadaan yang memaksa, artinya jalan lain yang ditempuh gagal, maka presiden memiliki kewenangan untuk melakukan pencabutan hak, tanpa persetujuan subyek hak menurut UU No. 20 Tahun 1961; b). Asas-asas dalam penguasaan tanah dan perlindungan hukum bagi pemegang hak atas tanah, menurut Arie S. Hutagalung (2005), dalam Hukum Tanah Nasional dikemukakan asas-asas yang berlaku daam penguasaan tanah dan perlindungan hukum bagi pemegang hak atas tanah, yaitu: 1) Penguasaan dan penggunaan tanah oleh siapapun dan bagi keperluan siapapun dan untuk keperluan apapun, harus dilandasi hak pihak penguasa sekalipun, jika gangguan atas tanah yang disediakan oleh hukum tanah Nasional; 2) Penguasaan serta penggunaan tanah tanpa ada landasan haknya (illegal) tidak dibenarkan bahwa diancam dengan sanksi pidana; 3) Penguasaan dan penggunaan tanah yang berlandaskan hak yang disediakan oleh hukum tanah nasional, dilindungi oleh hukum terhadap gangguan dari pihak manapun, baik oleh sesama anggota masyarakat maupun oleh pihak penguasa sekalipun, jika gangguan tersebut tidak ada landasan hukumnya; 4) Hukum menyediakan berbagai sarana hukum dalam menanggulangi gangguan yang ada, yaitu gangguan oleh sesama anggota masyarakat: Gugatan Perdata melalui Pengadilan Negeri atau meminta perlindungan kepada Bupati/Walikotamadya menurut UU No.51 Prp Tahun 1960: dan gangguan oleh Penguasa: Gugatan melalui Pengadilan Tata Usaha Negara; 5) Dalam keadaan biasa diperlukan oleh siapapun dan untuk keperluan apapun (juga untuk proyek kepentingan umum) perolehan tanah yang dihaki seseorang harus melalui musyawarah untuk mencapai kesepakatan, baik mengenai penyerahan tanahnya kepada pihak yang memerlukan maupun mengenai imbalannya yang merupakan hak pemegang atas tanah yang bersangkutan untuk menerimanya; 6) Hubungan dengan apa yang tersebut diatas, dalam keadaan biasa, guna memperoleh tanah yang diperlukan tidak dibenarkan adanya paksaan dalam bentuk apapun dan oleh pihak siapapun kepada pemegang haknya, untuk menye- 
rahkan tanah kepunyaannya dan atau menerima imbalan yang tidak disetujuinya, termasuk juga penggunaann lembaga "penawaran pembayaran diikuti dengan konsinyasi pada Pengadilan Negeri" seperti yang diatur dalam Pasal 1404 Kitab UndangUndang Hukum Perdata; 7) Pada keadaan memaksa, apabila tanah yang bersangkutan diperlukan guna penyelenggaraan kepentingan umum, dan tidak mungkin digunakan tanah lain, sedang musyawarah yang diadakan tidak berhasil memperoleh kesepakatan, dapat dilakukan pengambilan secara paksa, dalam arti tidak memerlukan persetujuan pemegang haknya, dengan menggunakan acara "pencabutan hak" yang diatur pada UndangUndang Nomor 20 Tahun 1961; 8) Pada perolehan atau pengambilan tanah, baik atas dasar kesepakatan bersama maupun melalui pencabutan hak, pemegang haknya berhak memperoleh imbalan atau ganti kerugian, yang bukan hanya meliputi tanahnya, bangunan dan tanaman pemegang hak, melainkan juga kerugian-kerugian lain yang diderita sebagai akibat penyerahan tanah yang bersangkutan; 9) Bentuk dan jumlah imbalan atau ganti kerugian tersebut, juga apabila tanahnya diperlukan bagi kepentingan umum dan dilakukan pencabutan hak, haruslah sedemikian rupa, sampai bekas pemegang haknya tidak mengalami kemunduran, baik dalam bidang sosial maupun tingkat ekonominya.

Masalah ganti kerugian ini merupakan masalah yang sensitif, oleh karena itu proses pelaksanaan ganti kerugian harus memperhatikan asas-asas ganti kerugian yang tersirat beberapa asas hukum demi terciptanya perlindungan hukum seperti yang dinyatakan oleh Ediwarman, antara lain: Asas itikad baik adalah pengadaan tanah bagi kepentingan umum harus dilandasi dengan itikad baik, keterbukaan dan kejujuran dari kedua belah pihak, baik dari segi peruntukan, bentuk maupun besarnya nilai ganti yang diberikan. Sehingga kedua belah pihak tidak ada yang dirugikan dalam proses pelaksanaannya; Asas keseimbangan, asas ini menghendaki adanya keseimbangan antara hak dan kewajiban penguasaan tanah dalam setiap pemberian ganti kerugian, baik dalam bentuk dan besarnya; Asas kepatutan, Nilai ganti kerugian haruslah layak dan patut berdasarkan nilai nyata/ sebenarnya dari tanah dan/ atau segala yang menjadi turutannya. Kalau bisa harga tersebut menjadi harga yang lebih tinggi dari harga umum dan harga catut; Asas kepastian hukum, perlindungan hukum bagi semua masyarakat dan sebisa mungkin semua masyarakat terbebas dari praktek-praktek penyalahgunaan wewenang dalam ganti kerugian tanah. Dalam Undang-Undang Nomor 2 Tahun 2012 harus memuat sanksi-sanksi hukumnya agar kepastian hukum bisa tercapai; dan Asas kesejahteraan, asas ini menghendaki perlindungan terhadap pihak yang melepaskan tanah dari sisi ekonominya. Perlindungan hukum harus konkrit dengan menerapkan sanksi yang bersifat penal dan non-penal. Sanksi yang bersifat penal terhadap pelaku yang telah melakukan penyalahgunaan wewenang harus dihukum dan sanksi yang bersifat non-penal dapat diberikan yang bernilai ekonomis guna kesejahteraan korban.

\section{Metode}

Jenis penelitian dalam menggunakan penelitian normatif-empiris. Penelitian normatif-empiris yaitu penelitian yang dilakukan untuk menelaah kaidah hukum normatif yang dilihat dari segi penerapannya. Dalam penentuan ganti rugi untuk pembangunan untuk kepentingan umum yang dilaksanakan secara musyawarah.

\section{Pembahasan}

\subsection{Pelaksanaan Pembangunan Untuk Kepentingan Umum}

Tahapan pengadaan tanah menurut UU Pengadaan Tanah dibagi menjadi tiga, yaitu:1) Perencanaan, Instansi yang membuthkan tanah 
membuat perencanaan yang sesuai dengan Rencana Tata Ruang Wilayah (RTRW) dan prioritas pembangunan yang tercantum dalam Rencana Pembangunan Jangka Menengah (RPJM), Rencana Strategis, Rencana Kerja Pemerintah Instansi yang bersangkutan. Perencanaan tersebut berupa "dokumen perencanaan pengadaan tanah" yang disusun berdasarkan "studi kelayakan" (Limbong, 2015). Dokumen Perencanaan Pemgadaan Tanah, berupa: maksud tan tujuan rencana pembangunan; kesesuaian dengan RTRW dan Rencana Pembangunan Nasional dan Daerah; letak tanah; luas tanah yang dibutuhkan; gambaran umum status tanah; perkiraan jangka waktu pelaksanaan pengadaan tanah; perkiraan nilai tanah; dan rencana penganggaran. Sedangkan studi kelayakan, meliputi: survei sosial ekonomi; kelayakan lokasi; analisis biaya dan manfaat pembangunan bagi wilayah dan masyarakat; perkiraan nilai tanah; dampak lingkungan dan dampak sosial yang mungkin timbul akibat dari pengadaan tanah dan pembangunan; dan studi lain yang diperlukan. 2) Persiapan, Instansi yang memerlukan tanah bersama Pemerintah Preopinsi berdasarkan dokumen perencanaan pembangunan memberitahukan rencana pembangunan kepada masyarakat. Baik langsung maupun tidak langsung melakukan pendataan awal lokasi rencana pembangunan, dan melakukan konsultasi publik rencana pembangunan. Pendataan awal lokasi dilakukan paling lama 30 (tiga puluh) hari kerja sejak pemberitahuan rencana pembangunan. Pendataan awal lokasi meliputi kegiatan pengumpulan awal Pihak yang Berhak dan obyek Pengadaan Tanah. Kesepakatan untuk mendapatkan tanah tersebut dilakukan setelah ada musyawarah, Jika ternyata ada keberatan-keberatan, Gubernur membentuk tim yang mengkaji atas keberatan tersebut dan Gubernur akan merekomendasi diterima atau ditolaknya keberatan atas rencana lokasi. Apabila ditolak, maka Gubernur akan memberitahukan kepada Instansi yang memerlukan tanah untuk mengajukan rencana lokasi pembangunan ditempat lain. Tetapi kalau masih ada keberatan terhadap penetapan lokasi, pihak yang berhak terhadap penetapan lokasi dapat mengajukan gugatan ke Pengadilan Tata Usaha Negara (PTUN). Pihak yang keberatan dengan putusan PTUN dapat mengajukan kasasi kepada Mahkamah Agung (Limbong, 2015).

Penetapan lokasi pembangunan diberikan dalam waktu 2 (dua) tahun dan dapat diperpanjang 1 (satu) tahun. Dalam hal jangka waktu penetapan lokasi pembangunan tidak terpenuhi, penetapan lokasi pembangunan untuk kepentingan Umum dilakukan proses ulang terhadap sisa tanah yang belum selesai pengadaannya dan Gubernur bersama Instansi yang memerlukan tanah mengumumkan penetapan lokasi pembangunan sebagai pemberitahuan kepada masyarakat bahwa dilokasi tersebut akan dilaksanakan pembangunan untuk kepentingan umum.

Pelaksanaan Pengadaan Tanah, Setelah mendapatkan penetapan lokasi pembangunan, Instansi yang memerlukan tanah mengajukan pelaksanaan pengadaan tanah kepada Lembaga Pertanahan. Adapun yang ldimaksud dengan Lembaga Pertanahan yaitu Badan Pertanahan Nasional Republik Indonesia, lembaga pemerintah yang menyelenggarakan urusan pemerintahan di bidang pertanahan. Pelaksanaan pengadaan tanah meliputi: a) Inventarisasi dan Identifikasi. Infentarisasi dan Identifikasi ini meliputi kegiatan pengukuran dan pemetaan bidang perbidang tanah; dan pengumpulan data Pihak yang Berhak dan obyek pengadaan tanah. Semuanya dilakukan dalam waktu paling lama 30 (tiga puluh) hari kerja. Hasil dari infentarisasi dan identifikasi yang meliputi subyek hak, luas, letak dan peta bidang tanah obyek pengadaan tanah wajib diumumkan di kantor Desa/ Kelurahan, kantor Kecamatan dan tempat pengadaan tanah dilakukan. b) Penilaian ganti kerugian. Penilaian besarnya nilai ganti kerugian oleh penilai yang diumumkan lembaga Pertanahan, dilakukan bidang perbidang tanah seperti yang diatur dalam Pasal33 Undang-Undang Pengadaan tanah, meliputi: 
Tanah; ruang atas tanah dan bawah tanah; bangunan; tanaman; benda yang berkaitan dengan tanah; dan/atau, kerugian lain yang dapat dinilai.

Dalam penjelasan Pasal 33 huruf f bahwa kerugian lain yang dapat dinilai adalah kerugian non fisik yang dapat disetarakan dengan uang, misalnya kerugian karena kehilangan usaha atau pekerjaan, biaya pemindahan tempat, biaya alih profesi, dan nilai atas property sisa. Nilai ganti kerugian yang dinilai merupakan nilai pada saat pengumuman Besarnya ganti kerugian disampaikan kepada Lembaga Pertanahan dengan Berita Acara dan menjadi dasar musyawarah penetapan Ganti Kerugian (Limbong, 2015).

Dalam pengadaan tanah untuk kepentingan umum pemegang hak atas tanah harus mendapat ganti kerugian yang adil yang menjadi haknya ketika melepaskan hak atas tanahnya. Ganti kerugian yang disebut adil apabila keadaan setelah pengambilalihan tanah paling tidak kondisi sosial ekonominya setara dengan keadaan sebelumnya, di samping itu ada jaminan terhadap kelangsungan hidup mereka yang tergusur (Sumardjono, 2008). Dengan kata lain, asas keadilan harus dikonkritkan dalam pemberian ganti kerugian, artinya dapat memulihkan kondisi sosial ekonomi mereka minimal setara atau setidaknya masyarakat tidak menjadi miskin dari sebelumnya (Achmad Rubaie, 2007).

c) Pelepasan TanahPelepasan adalah kegiatan pemutusan hubungan hukum dari Pihak yang Berhak kepada Negara melalui lembaga pertanahan. Pelepasan tanah Instansi yang diatur dalam Pasal 45 UU pengadaan tanah yang terdiri dari 3 ayat, yaitu: ayat (1) Pelepasan obyek pengadaan tanah untuk kepentingan umum yang dimiliki Pemerintah dilakukan sesui dengan ketentuan Peraturan perundang undangan yang mengatur pengelolaan barang milik Negara/Daerah. Ayat (2) Pelepasan obyek pengadaan tanah untuk kepentingan umum ini dikuasai oleh Badan Usaha Milik Negara/Badan Usaha Milik Daerah dilakukan berdasarkan undang-undang pengadaan tanah dalam ayat (3). Pelepasan ini dilakukan oleh pejabat yang berwenang atau pejabat yang diberi pelimpahan untuk itu. Pelepasan obyek pengadaan tanah seperti yang dimaksud dalam Ayat (1) dan (2) tidak diberikan ganti kerugian, kecuali obyek pengadaan tanah yang telah berdiri bangunan yang dipergunakan secara aktif untuk penyelenggaraan tugas pemerintahan. Selain itu obyek pengadaan tanah yang dimiliki/dikuasai oleh Badan Usaha Milik Negara/Badan Usaha Milik Daerah dan/atau obyek pengadaan tanah kas desa.

Pelepasan obyek pengadaan tanah tersebut dilaksanakan paling lama 60 (enam puluh) hari kerja sejak penetapan lokasi pembangunan bagi kepentingan umum. Apabila telah melebihi batas waktu yang ditentukan tersebut, maka tanahnya dinyatakan telah dilepaskan dan menjadi tanah Negara dan dapat langsung digunakan untuk pembangunan bagi kepentingan umum. Pejabat yang melanggar ketentuan ini akan dikenakan sanksi administrasi sesuai dengan ketentuan peraturan perundang undangan. Instansi yang memperoleh tanah wajib untuk mendaftarkan tanahnya. Sedangkan lembaga pertanahan wajib melakukan pemantauan dan evaluasi hasil penyerahan pengadaan tanah untuk kepentingan umum yang diperoleh. d) Pemberian Ganti Kerugian. Pada dasarnya pemberian ganti kerugian itu harus diserahkan langsung kepada Pihak yang Berhak menerima. Hal ini dimaksudkan supaya tidak terjadi penyimpangan yang tidak diharapkan. Tentu saja bentuk dan besarnya ganti kerugian tersebut harus sesuai dengan hasil musyawarah untuk mufakat antara Lembaga Pertanahan dengan Pihak yang Berhak.

Hasil penilaian itu ditetapkan dalam musyawarah dan/atau putusan Pengadilan Negrai/ Mahkamah Agung. Pada saat pemberian ganti kerugian Pihak yang Berhak menerima ganti kerugian wajib melakukan pelepasan hak dan menyerahkan bukti penguasaan dan kepemilikan obyek 
pengadaan tanah kepada Instansi yang memerlukan tanah melalui lembaga pertanahan (Limbong, 2015). Yang dimaksudkan dengan pihak yang berhak adalah pihak yang menguasai atau memiliki obyek pengadaan tanah, yang meliputi: pemegang hak atas tanah; pemegang hak pengelolaan; nadzir, untuk tanah wakaf; pemilik tanah bekas milik adat; masyarakat hukum adat; pihak yang menguasai tanah Negara denga itikad baik; pemegang dasar penguasaan atas tanah; dan/atau pemilik bangunan, tanaman atau benda lain yang berkaitan dengan tanah.

Selanjutnya Bernhard Limbong menyatakan bahwa pihak yang telah menerima ganti kerugian harus meyakinkan akan kebenaran dan keabsahan bukti penguasaan atau kepemilikan yang di serahkan. Umumnya, dalam pengadaan tanah "ganti kerugian" sering disebut dengan "kompensasi" dan kompensasi ini dibedakan kompensasi atas faktor fisik (materiil) meliputi penggantian atas: Tanah hak baik yang bersertipikat dan yang belum bersertipikat, tanah ulayat, tanah wakaf, tanah yang dikuasai tanpa alas hak yang dengan atau tanpa ijin pemilik tanah, bangunan, tanaman, benda-benda lain yang ada kaitannya dengan tanah. Sedangkan kompensasi atas faktor non-fisik (immaterial), yaitu penggantian atas kehilangan, keuntungan, kenikmatan, manfaat atau kepentingan yang sebelumnya diperoleh oleh masyarakat yang terkena pembangunan sebagai akibat pembangunan tersebut (Bernhard Limbong, 2015: 188).

Mengenai bentuk dan kompensasi diperhitungkan sedemikian rupa supaya masyarakat yang terkena dampak pembangunan untuk kepentingan umum ini kondisi sosial ekonominya minimal setara dengan kondisi awal sebelum pelepasan tanah ataupun tidak mengalami kemunduran.

Lembaga pertanahan menyerahkan hasil pengadaan tanah kepada Instansi yang memerlukan tanah. Hal ini dilakukan setelah pemberian ganti kerugian kepada pihak yang berhak dan pelepasan atau pemberian ganti kerugian kepada pihak yang berhak dan pelepasan hak dan/atau pemberian ganti mkerugian telah dititipkan di PN. Instansi yang membutuhkan tanah dapat segera membangun sesuai dengan rencananya tentunya setelah selesai dilakukan serah terima hasil pengadaan tanahnya.Yang terpenting pihak yang berhak dapat menjamin tanahnya tidak bermasalah/ dalam sengketa dan memang itu sah kepemilikannya. Sedangkan bagi instansi yang memerlukan tanah bisa segera mendaftarkan tanahnya agar mendapatkan kepastian dan perlindungan hukam.

Dalam keadaan mendesak akibat bencana alam, perang, konflik sosial yang meluas dan wabah penyakit pengadaan tanah dapat langsung dilaksanakan pembangunannya setelah dilakukan penetapan lokasi pembangunan. Sebelumnya terlebih dahulu disampaikan kepada Pihak yang Berhak. Instansi yang memerlukan tanah tetap dapat melaksanakan kegiatan pembangunan walaupun ada keberatan atau gugatan atas pelaksanaan pengadaan tersebut.

kepentingan lumum pada Pasal 1 angka 6 Undang-Undang Pengadaan Tanah, adalah kepentingan bangsa,negara, dan masyarakat yang harus diwujudkan oleh pemerintah dan digunakan sebesar-besarnya untuk kemakmuran rakyat. Pemerintah dan/atau Pemerintah Daerah menjamin tersedianya tanah untuk kepentingan umum dan pendanaannya. Pengadaan tanah untuk kepentingan umum diselenggaran oleh Pemerintah. Pengadaan tanah untuk kepentingan umum diselenggarakan sesuai dengan: Rencana Tata Ruang Wilayah; Rencana Pembangunan Nasional/Daerah; Rencana Strategis; dan Rencana kerja setiap instansi yang memerlukan tanah. Tanah untuk kepentingan umum sebagaimana dimaksud dalam Pasal 4 ayat (1) digunakan untuk pembangunan: Pertahanan dan keamanan nasional; Jalan umum, jalan tol, terowongan, jalur kereta api, stasiun kereta api, dan fasilitas kereta api; Waduk, bendungan, bendung, irigasi, saluran air minum, saluran pem- 
buangan air dan sanitasi, dan bangunan pengairan lainnya; Pelabuhan, lbandar udara, dan terminal; Infrastruktur minyak, gas, dan panas bumi; Pembangkit, transmisi, gardu, jaringan, dan distribusi tenaga listrik; Jaringan telekomunikasi dan informatika Pemerintah; Tempat pembuangan dan pengolahan sampah; Rumah sakit Pemerintah/ Pemerintah Daerah; Fasilitas keselamatan umum; Tempat pemakaman umum Pemerintah/Pemerintah Daerah; Fasilitas sosial, fasilitas umum, dan ruang terbuka hijau publik; Cagar alam dan cagar budaya; Kantor Pemerintah/Pemerintah Daerah/ desa; Penataan permukiman kumuh perkotaan dan/atau konsolidasi tanah, serta perumahan untuk masyarakat berpenghasilan rendah dengan status sewa; Prasarana pendidikan atau sekolah Pemerintah/Pemerintah Daerah; Prasarana olah raga Pemerintah/Pemerintah Daerah; dan Pasar umum dan lapangan parkir umum.

Konsultasi publik rencana pembangunan dilakukan oleh Pihak yang Berhak dengan masyarakat yang terkena dampak serta tempat rencana pembangunan untuk kepentingan umum. Dengan kesepakatan keduanya, instansi yang memerlukan tanah mengajukan permohonan penetapan lokasi kepada Gubernur dan Gubernur menetapkan lokasi paling lama 14 (empat belas) hari kerja terhitung sejak diterimanya permohonan penetapan oleh Instansi yang memerlukan tanah. Konsultasi publik rencana pembangunan untuk kepentingan umum berjangka waktu 60 (enam puluh) hari kerja. Selama waktu yang ditentukan ini masih ada pihak yang keberatan dengan rencana pembangunan tersebut, maka akan dilakukan konsultasi publik ulang dengan pihak yang keberatan dalam waktu paling lama 30 (tiga puluh) hari kerja.

Apabila dalam konsultasi publik ini masih ada pihak yang keberatan mengenai rencana lokasi pembangunan, Instansi yang membutuhkan tanah harus melaporkan kepada Gubernur dan Gubernur akan membentuk tim untuk mengkaji keberatan rencana lokasi pmbangunan tersebut. Segera tim akan mendapatkan hasil berupa rekomendasi diterima atau ditolaknya keberatan rencana lokasi pembangunan dalam waktu paling lama 14 (empat belas) hari kerja sejak diterimanya permohonan oleh Gubernur dan berdasarkan rekomendasi tersebut Gubernur akan mengeluarkan surat diterimanya/ditolaknya keberatan tersebut.

Apabila keberatan atas rencana pembangunan ditolak, Gubernur akan menetapkan lokasi pembangunan. Gubernur segera memberitahukan kepada instansi yang memerlukan tanah untuk segera mengajukan rencana lokasi pembangunan di tempat lain. Apabila setelah penetapan lokasi oleh Gubernur masih ada Pihak yang Berhak merasa keberatan, maka mereka dapat mengajukan gugatan kapada Pengadilan Tata Usaha Negara (PTUN) paling lambat 30 (tiga puluh) hari kerja sejak dikeluarkannya penetapan lokasi. PTUN akan memutuskan diterima/ditolaknya gugatan dalam waktu 30 (tiga puluh) hari kerja sejak diterimanya gugatan. Atas putusan PTUN tersebut bagi Pihak yang Berhak masih keberatan juga dengan putusan tersebut, mereka diberikan waktu 14 (empat belas) hari kerja dalam mengajukan kasasi kepada Mahkamah Agung Republik Indonesia. Putusan pengadilan yang sudah memiliki kekuatan hukum tetap itulah yang dipakai dasar untuk diteruskan atau tidaknya Pengadaan Tanah.

\subsection{Kegagalan Musyawarah Dalam Penentuan Ganti kerugian}

Musyawarah di dalam penentuan bentuk dan/ atau besarnya ganti kerugian sangat diperlukan. Musyawarah ini dilakukan berdasarkan hasil penilaian ganti kerugian dari penilai. Penilai adalah orang perseorangan yang melakukan penilaian secara indipenden dan professional yang telah mendapat ijin praktek penilaian dari Menteri Keuangan.

Pelaksanaan pengadaan tanah dengan musyawarah untuk mufakat mengenai rencana lokasi pembangunan, bentuk dan/atau besarnya ganti 
kerugian, pengadaan tanah dapat berjalan sesuai dengan rencana. Peroehan tanah pembangunan baik melalui kata sepakat ataupun pencabutan tanah (perolehan tanah yang dilakukan dengan cara biasa tidak tercapai kata sepakat dan rencana pembangunannya tidak dapat digantikan ditempat lain), terhadap subyek hak wajib diberikan imbalan ganti kerugian yang layak berupa uang, fasilitas/tanah pengganti sehingga keadaan sosial ekonominya tidak merosot/menurun (Sumardjono, 2001).

Masalah ganti kerugian dalam pengadaan tanah merupakan masalah yang pelik. Sejalan dengan perkembangan zaman yang semakin maju, musyawarah yang menuntut ganti kerugian dengan nilai nyata yang sesuai dengan harga umum di pasaran, bukan berdarkan harga Nilai Jual Obyek Pakaj (NJOP). Menurut Aburrahman (1996), pemberian ganti kerugian berdasarkan NJOP itu tidak memberikan kepuasan, tidak bermanfaat dan malah merugikan.

Dalam menentukan besarnya ganti kerugian besarnya ganti kerugian atas tanah lebih sulit dibandingkan dengan ganti kerugian atas bangunan dan tanaman, karena masih ada beberapa faktor yang mempengaruhi harga tanah. Hal ini menjadi pertimbangan dalam penentuan besarnya ganti kerugian, di samping perhitungan berdasarkan NJOP Bumi dan Bangunan tersebut. Adapun faktor-faktor tersebut adalah: Penentuan lokasi letak tanah, ini berkaitan dengan apakah daerah tersebut merupakan daerah yang strategis atau kurang strategis; Status penguasaan tanah, misalnya apakah yang menguasai tanahnya adalah pemegang hak yang sah atau hanya penggarap; Status hak atas tanah, apakah hak milik, hak guna bangunan, hak pakai, dan lain-lain; Kelengkapan sarana prasarana, misalnya lokasi tersebut berdekatan dengan Bandar/kota, pusat perbelanjaan, jalan utama dan lain-lain; Keadaan fisik tanahnya/ misalnya terpelihara atau terlantar; Kerugian sebagai akibat dipecahnya hak atas tanah tersebut;
Biaya pindah tempat atau biaya pengerjaan; dan Kerugian terhadap turunnya penghasilan si pemegang hak, misalnya kedainya yang banyak pelanggan menjadi berkurang karena pindah lokasi (Sutedi, 2007).

Apabila pihak yang Berhak atas besarnya ganti kerugian, Undang-Undang Nomor 2 Tahun 2012 memberikan cara penyelesaiannya, yaitu didasarkan atas kesepakatan dalam musyawarah antara Pihak yang Berhak dengan Lembaga Pertanahan. Lembaga Pertanahanlah yang berhak menentukan bentuk dan besarnya ganti kerugian. Dalam tidak terjadi kespakatan mengenai bentuk dan/atau besarnya ganti kerugian, kepada Pihak yang Berhak diberikan waktu 14 untuk mengajukan keberatan ke Pengadilan Negeri setempat setelah musyawarah penetapan ganti kerugian. Pengadilan negeri akan memutus bentuk dan/atau besarnya ganti kerugian dalam waktu paling lama 30 (tiga puluh) hari kerja sejak diterimanya pengajuan keberatan (Pasal 38 ayat (1) Undang-Undang No. 2 Tahun 2012).

Undang-Undang Pengadaan Tanah tidak ditemukan istilah "Musyawarah" tetapi digunakan istilah "Konsultasi Publik". Konsultasi publik adalah proses komunikasi dialogis atau musyawarah antar pihak yang berkepentingan guna mencapai kesepahaman dan kesepakatan dalam perencanaan pengadaan tanah bagi pembangunan untuk kepentingan umum.

Musyawarah dalam pelaksanaan pengadaan tanah untuk kepentingan umum mempunyai makna yang penting, dalam 2 (dua) hal: pertama, menentukan dapat atau tidaknya pengadaan tanah untuk kepentingan umum dilaksanakan. Kedua, menentukan bentuk dan besarnya ganti kerugian yang akan diterima oleh pemegang hak atas tanah.

Menurut Pasal 37 ayat (1) dan (2) UndangUndang Pengadaan Tanah diatur bahwa lembaga pertanahan melakukan musyawarah dengan Pihak yang Berhak dalam waktu 30 (tiga puluh) hari kerja sejak hasil penilaian dari penilai disampaikan 
kepada Lembaga Pertanahan untuk menetapkan bentuk dan / atau besarnya ganti kerugian berdasarkan hasil penilaian ganti kerugian.

Hasil kesepakatan dalam musyawarah tersebut menjadi dasar pemberian Ganti Kerugian kepada Pihak yang Berhak yang dimuat dalam berita acara kesepakatan. Jika tidak terjadi kesepakatan tentang bentuk dan / atau besarnya ganti kerugian, pihak yang keberatan dapat menuntut melalui Pengadilan Negri dalam waktu 14 (empat belas) hari kerja setelah musyawarah penetapan ganti kerugiannya. Pengadilan negri memutus bentuk dan / atau besarnya ganti kerugian dalam waktu paling lama 30 (tiga puluh) hari kerja sejak diterimanya pengajuan keberatan. Pihak yang keberatan terhadap putusan pengadilan negri, maka dalam waktu 14 (empat belas) hari kerja dapat mengajukan kasasi kepada Mahkamah Agung RI dan Mahkamah Agung wajib memutuskan dalam waktu 30 (tiga puluh) hari kerja sejak permohonan kasasi. Dalam hal pihak yang bisa menolak bentuk dan/ atau besarnya ganti kerugian tetapi tidak mengajukan keberatannya dalam waktu yang ditentukan, karena hukum Pihak yang Berhak dianggap telah menerima bentuk dan besarnya ganti kerugian tersebut.

Pihak yang Berhak menolak bentuk dan/ atau besarnya ganti kerugian berdasarkan hasil musyawarah, atau putusan Pengadilan Negeri atau Mahkamah Agung yang telah memperoleh kekuatan hukum yang tetap, ganti kerugian akan dititipkan (konsinyasi) di Pengadilan Negeri setempat (Pasal 42 Undang-Undang Nomoe 2 Tahun 2012). Penitipan ganti kerugian selain di atau diberikan kepada Pihak yang Berhak yang menolak bentuk, tetapi juga diberikan terhadap: Pihak yang Berhak menerima ganti kerugian yang keberadaannya tidak diketahui atau tidak diketemukan dan Obyek Pengadaan Tanah yang akan diberikan ganti kerugian, yang sedang menjadi obyek perkara di Pengadilan, masih dipersengketakan kepemilikannya, diletakkan sita oleh pejabat yang berwenang, menjadi jaminan Bank.

Pemberian ganti kerugian dan pelepasan hak atas tanah telah dilaksanakan atau pemberian ganti kerugian telah dititipkan di Pengadilan Negeri (konsinyasi), kepemilikan atau hak atas tanah dari Pihak yang Berhak menjadi hapus dan alat bukti haknya tidak berlaku dan tanahnya menjai dikuasai langsung oleh Negara (Pasal 43 Undang-Undang Nomor 2 Tahun 2012).

\section{Simpulan}

Apabila Pihak yang Berhak keberatan mengenai besarnya ganti kerugian, maka UndangUndang Nomor 2 Tahun 2012 lah yang memberikan jalan cara penjelasan yang didasarkan atas kesepakatan dalam musyawarah antara Lembaga Pertanahan dengan Pihak yang Berhak. Apabila tidak terjadi kesepakatan tentang ganti kerugian tersebut ditempuh melalui Pengadilan Negeri atau Mahkamah Agung sesuai dengan waktu yang ditentukan. Dalam hal Pihak yang Berhak tetap menolak berdasarkan hasil musyawarah atau putusan Pengadilan Negeri atau Mahkamah Agung, maka ganti kerugian tersebut dititipkan (konsinyasi) Pengadilan Negeri.

\section{Daftar pustaka}

Abdurrahman. 1996. Menelaah Pencabutan Hak Atas Tanah, Pembebasan Tanah dan Pengadaan Tanah Bagi Pelaksanaan Pembangunan Untuk Kepentingan Umum di Indonesia. Bandung. Citra Aditya Bakti.

Ediwarman. 2001. Perlindungan Hukum Bagi Korban Kasuskasus Pertanahan di Sumatera Utara. Disertasi. Program Pascasarjana, Universitas Medan. Sumatera Utara.

Harsono, Boedi. 2013. Hukum Agraria Indonesia, Sejauh Pembentukan Undang-undang Pokok Agraria, Isi dan Pelaksanaannya. Jilid I. Jakarta. Penerbit Universitas Trisaksi.

Hutagalung, Arie S. 2005. Seputar Masalah Hukum Tanah. Jakarta, LPHI. 


\section{Jurnal Cakrawala Hukum, Volume 9 No. 2 Desember 2018}

ISSN PRINT 2356-4962 ISSN ONINE 2598-6538

Limbong, Bernhard. 2015. Pengadaan Tanah Untuk Pembangunan. Jakarta. Pustaka Margaretha.

Mahendra, A.A. Oka. 1996. Mengenal Masalah Hukum, Demokrasi dan Pertanahan. Jakarta. Sinar Harapan.

Pragmatie. 2012. UU Pengadaan Tanah. Harian Kompas.

Rubaie, Achmad. 2007. Hukum Pengaaan Tanah untuk Kepentingan Umum. Cetakan Pertama. Malang. Bayumedia Publishing.

Sumardjono, Maria SW. 2001. Kebijakan Pertanahan antara Regulasi dan Implementasi. Jakarta. Buku Kompas.

Suryaningtyas, Toto. 2005. Sulitnya Menepis BayangBayang Masa Lalu. Jakarta. Kompas.
Sutedi, Adrian. 2007. Implementasi Prinsip Kepentingan Umum dalam Pengadaan Tanah Untuk Pembangunan. Jakarta. Sinar Grafika.

Umar Said Sugiharto, Suratman Noorhudha, Muchsin. 2015. Hukum Pengadaan Tanah - Pengadaan HAT untuk kepentingan umum Pra \& Paska Reformasi. Malang. Setara Press.

Undang-Undang Nomor 39 Tahun 1999 Tentang Hak Asasi Manusia.

Undang-Undang Nomor 2 Tahun 2012 Tentang Pengadaan Tanah Bagi Penbangunan Untuk Kepentingan Umum. 